\title{
MEETING COMPETITION AND THE SUN OIL CASE: REPUDIATION OF THE ENTERPRISE DOCTRINE
}

Although Section 2(a) of the Clayton Act, as amended by the RobinsonPatman Act, 1 makes it unlawful under certain circumstances for a seller to discriminate in price between different purchasers, Section 2(b) of the Robinson-Patman Act ${ }^{2}$ permits a seller to rebut a prima facie case of price discrimi-

138 Stat. 730 (1914), as amended, 49 Stat. 1526 (1936), 15 U.S.C. 813 (a) (1952). Section 2(a), in pertinent part, provides:

"It shall be unlawful for any person engaged in commerce . . . to discriminate in price between different purchasers ... . where the effect of such discrimination may be substantially to lessen competition or tend to create a monopoly in any line of commerce, or to injure, destroy, or prevent competition with any person who either grants or knowingly receives the benefit of such discrimination, or with the customers of either of them...." Section 2(a) provides three "justifications" to a charge of price discrimination: differentials in price making due allowance for cost; customer selection in bona fide transactions and not in restraint of trade; and price changes from time to time in response to changing market conditions. While each of these is a complete defense, none is likely to prove sucoessful. Adelman, The Consistency of the Robinson-Patman Act, 6 STAN. L. REV. 3, 14 (1953); Rowe, Cost Justification of Price Differentials Under the Robinson-Patman Act, 59 Colum. L. Rev. 485 (1959).

Where the alleged injury is to non-favored purchasers (i.e., "secondary line" injury), mere proof of a substantial difference in price, without more, has raised a presumption of probability that competition may be substantially lessened. FTC v. Morton Salt Co., 334 U.S. 37, 46-50 (1948); Standard Oil Co. v. FTC, 340 U.S. 231 (1951); Standard Motor Prods., Inc. v. FTC, 265 F.2d 674, 676 (2d Cir. 1959), cert. denied, 361 U.S. 826 (1959). But cf. Minneapolis-Honeywell Regulator Co. v. FTC, 191 F.2d 786, 792 (7th Cir. 1951), cert. dismissed for lateness in filing, 344 U.S. 206 (1952).

Where the injury alleged is to competition at the seller's level (i.e., "primary line" injury), substantial proof of the capacity of the seller to divert business to him and away from other sellers, if not proof of actual diversion of business, has been required. Anheuser-Busch, Inc. v. FTC, 289 F.2d 835 (7th Cir. 1961); Balian Ice Cream Co. v. Arden Farms Co., 104 F. Supp. 796 (S.D. Cal. 1952), aff'd, 231 F.2d 356 (9th Cir. 1955), cert. denied, 350 U.S. 991 (1956). See also General Gas Corp. v. National Util., Inc., 271 F.2d 820 (5th Cir. 1959); Gerber Prods. Co., v. Beech-Nut Life Savers, Inc., 160 F. Supp. 916 (S.D.N.Y. 1958). To the extent that Samuel H. Moss, Inc. v. FTC, 148 F.2d 378 (2d Cir. 1945), cert. denied, 326 U.S. 734 (1945), rehearing denied, 326 U.S. 80 (1945), motion denied, 155 F.2d 1016 (2d Cir. 1946), leads to a different conclusion, it has been repudiated by the Commission, General Foods Corp., 50 F.T.C. 885 (1954), and by the critics. See Adelman, Geographical Price Differentials, 48 Il..B.J. 514, 524-27 (1960); Austin, Price Discrimination and Related Problems Under the Robinson-Patman Act 43 (2d ed. 1959); Austern, Required Competitive Injury and Permitted Meeting of Competition, CCH RoBInson-PATMan SYMPOSIUM 70 (1947).

It is not required that the favored and non-favored purchasers be in competition when the alleged injury is to the "primary line." Atlas Bldg. Prods. Co. v. Diamond Block \& Gravel Co., 269 F.2d 950 (10th Cir. 1959).

249 Stat. 1526 (1936), 15 U.S.C. §13(b) (1958). Section 2(b), in pertinent part, provides:

"Upon proof being made ... that there has been diserimination in price or services or facilities furnished, the burden of rebutting the prima-facie case thus made by showing justification shall be upon the person charged with a violation of this section, and unless justification shall be affirmatively shown, the Commission is authorized to issue an order terminating the discrimination; Provided, however, That nothing contained [herein] shall pre- 
nation by showing that his lower price to any purchaser was made in good faith to meet an equally low price of a competitor. The Supreme Court in Standard Oil Co. v. FTC 3 held that section $2(\mathrm{~b})$ is a substantive, complete defense to a charge of price discrimination, even though the effect of such discrimination may be to injure competition at a resale level. 4

In Enterprise Indus., Inc. y. Texas Co.5 a federal district court construed the phrase of section 2(b), "equally low price of a competitor," to mean that

vent a seller from rebutting the prima-facie case thus made by showing that his lower price or the furnishing of services or facilities to any purchaser ... was made in good faith to meet an equally low price of a competitor, or the services or facilities furnished by a competitor." Section 2(b) is inapplicable to Section 2(c) of the Clayton Act, as amended. FTC v. Washington Fish \& Oyster Co., 282 F.2d 595 (9th Cir. 1960). It is a complete defense to a section 2(e) charge. FTC v. Simplicity Pattern Co., 360 U.S. 55 (1959). The Commission is still opposed to 2(b) as a defense to a section 2(d) violation, Shulton, Inc., 3 TRADE REG. REP. I 15323 (FTC 1961) (3-2 decision), but one court of appeals has expressed a contrary view, Exquesito Form Brassiere, Inc. v. FTC, 1961 Trade Cases $\{70157$ (D.C. Cir. 1961).

3340 U.S. 231 (1951).

4 Id. at 250-51. The Court rejected the Commission interpretation of $\$ 2(\mathrm{~b})-$ that it was for the Commission to weigh the potentially injurious effects of a seller's price discrimination upon competition at all levels against the beneficial effect cf such discrimination at the seller's level to enable the seller to meet his competitor's lower price. The decision left the old Clayton Act defense of "meeting competition" relatively intact and may have violated the intentions of the authors of the Robinson-Patman Act. Id. at 251-67 (Reed, J., dissenting).

The decision has been variously received. See Rowe, The Evaluation of the RobinsonPatman Act: A Twenty-Year Perspective, 57 Colum. L. Rev. 1059 (1957). Cf. Wallace \& Douglas, Antitrust Policies and the New Attack on the Federal Trade Commission, 19 U. CHI. L. REv. 684, 703-10 (1952). Legislative attempts to "codify" Standard Oil (e.g., H.R. 4170, 83d Cong., 1st Sess. (1953)), as well as attempts to repudiate the case (e.g., S.11, 86th Cong., 1st Sess. (1959)), have met with failure. Critics of the proposed "equality of opportunity" legislation such as $S .11$ argue that the effect would be to make $\$ 2(b)$ a nullity. See Duffner, Review and Analysis of Pending Bills for Amendment of Clayton Act, 8 ABA ANTrrrusT SECTION 125, 128-29 (1956); Rowe, supra. But the good faith meeting of a competitor's equally low price is not "a logical rebuttal which dispels any inference of inimical effects on competition that might otherwise have been causally attributed to his prices...." Rowe, supra at 1087-88 n.172. The proof which will satisfy the requirements of section 2(b) will not "necessarily and automatically prevent any tenable finding of detriment to competition." Ibid. The Supreme Court merely stated the difficulty in balancing the effects on competition at secondary or tertiary levels against the seller's meeting competition at its own level. Standard Oil Co. v. FTC, 340 U.S. 231, 251 (1951). The distinction may be drawn between discriminations in price causing injury to competitors of the seller, when meeting the competitor's lower price is of the essence of competition, and discriminations in price causing injury to non-favored purchasers or competitors of the favored buyer, or injury to the disfavored buyer's customers. In the latter two situations "meeting competition" is perfectly consistent with resulting injury to competition. See AusTin, op. cit. supra note 1, at 95. The "objective test" of injury to competition will not "nullify" the substantive nature of the section 2(b) defense if confined to secondary or tertiary line cases. If no price discrimination is per se illegal, none should be per se legal. But see Rowe, Price Discrimination. Competition and Confusion: Another Look at Robinson-Patman, 60 Y ALE L.J. 929, 969 n.261 (1951).

5136 F. Supp. 420 (D. Conn. 1955), rev'd on other grounds, 240 F.2d 457 (2d Cir. 1957), cert. denied, 353 U.S. 965 (1957). 
a seller could grant a lower price to a buyer only when that buyer had been offered an equally low price by a competitor of the seller. The defense would be available to a seller to permit him to meet his competition but not his buyer's competition. 6

The Fifth Circuit in Sun Oil Co. v. FTC7 re-examined Enterprise in the context of gasoline price war conditions at the retail level in Jacksonville, Florida. The court in Sun Oil held that the section 2(b) defense was available to a supplier of gasoline that reduced its wholesale price to one of its filling stations engaged in a price war with a competitor at the retail level. Although court and Commission decisions cast light on other issues arising under the "meeting competition" defense, 8 there was no direct precedent to guide the

- The district court's holding is ambiguous, since the court first argued that the defense was not satisfied and then argued that it was not available to Texas Company. 136 F. Supp. at 421 . It is apparent that if a defense is not available then it is irrelevant to speak about whether or not it is satisfied. On appeal to the Second Circuit, the district court was reversed on the question of plaintiff's damages. Judge Learned Hand's opinion indicated, howeve:; a sympathy for the "meeting competition" defense as argued by Texas Company. 240 F.2d at 458 .

The construction of the section 2(b) defense.by the district court has been recognized by some commentators as an accurate one. See Apsey, Establishing Meeting Competition Defense to Charge of Price Discrimination Under Robinson-Patman Act, 3 PRACT. LAw. 76, 77 (1957); Berger \& Goldstein, Meeting Competition Under the Robinson-Patman Act, 44 ILL. L. REv. 315, 325 (1949); Simon, Price Discrimination to Meet Competition, 1950 U. ILL. L.F. 575, 589. But see Note, The Good Faith Defense of the Robinson-Patman Act: A New Restriction Appraised, 66 Y ALE L.J. 935, 939 (1957).

7294 F.2d 465 (5th Cir. 1961).

8 It is agreed that section 2(b) refers to individual situations and not to competitive conditions generally. Standard Motor Prods., Inc. v. FTC, 265 F.2d 674, 677 (2d Cir. 1959). The discrimination must be temporary and not part of a pricing system. FTCv. Staley Mfg. Co., 324 U.S. 746 (1945). It has been said that the action taken must be defensive rather than aggressive. Standard Oil Co. v. FTC, 340 U.S. 231, 249 (1951). There must be an actual, present lower price of a competitor, for section 2(b) does-not refer to future, or hypothetical competition. Id. at 242; E. Edelmann \& Co. v. FTC, 239 F.2d 152 (7th Cir. 1956), cert. denied, 355 U.S. 941 (1958), rehearing denied, 356 U.S. 905 (1958). The discriminatory price must have been offered in good faith after careful investigation of the necessity of granting such lower price. FTC v. Staley Mfg. Co., supra at 759-60. Good faith precludes a seller from meeting a price which he knows or should know is illegal. Standard Oil Co. v. FTC, supra; Standard Oil Co. v. Brown, 238 F.2d 54 (5th Cir. 1956).

The problems of applying the above principles may be enumerated ad libitum. Some courts require the seller to establish the lawfulness of his competitor's price, surely an onerous burden requiring more than "good faith" should encompass. Enterprise Indus., Inc. v. Texas Co., 136 F. Supp. 420, 421 (D. Conn. 1955). It is not clear whether the competitor's lower price must in fact be a lawful one. Standard Oil Co. v. FTC, supra at 247 n.14, 250. See the dissent by Mr. Justice Douglas in FTC v. Standard Oil Co., 355 U.S. 396, 408 (1958): "It is only a lawful lower price that may be met." One writer argues that the competitive system is served only by limiting section 2(b) to unlawful lower prices. Note, Competitors' Lawful Prices and Lawful Competition, 43 MINN. L. REv. 327 (1958). But this conclusion demands an unwarranted interference with common business experience. The legality of the competitor's lower price should be no more than one factor to be considered in an inquiry of good faith. See Moorehead, Meeting "An Equally Low Price of a Competitor," 5 Antitrust Bull. 439, 443 (1960); Austin, op. cit. supra note 1, at 98-99.

Some courts have said that section 2(b) is limited to the retention of old customers. Standard Motor Prods. v. FTC, supra at 677 . Others have refused to draw a distinction 
court in Sun Oil aside from Enterprise.9 Seeking a construction of section 2(b) that would harmonize the Robinson-Patman Act and the antitrust laws, the Fifth Circuit rejected Enterprise and condoned the use of selective price concessions by a gasoline supplier to aid its retail outlet faced with an aggressive price-cutting competitor.

Swn Oil is based upon questionable hypotheses and creates new problems for the section 2(b) defense. The decision is not supported by the letter of the proviso, the legislative intent, or the relevant case law. It is instead a return

between retaining old customers and gaining new ones. Balian Ice Cream Co. v. Arden Farms Co., 104 F. Supp. 796, 801 (S.D. Cal. 1952) (dictum). Since it is possible to gain new customers and still do no more than hold one's share of the market, such a distinction seems ill-advised. But see Sunshine Biscuits Co., No. 7708, FTC, November 10, 1961.

Another area of conflict involves the question of whether a seller must meet exactly his competitor's price, or whether he may beat that price. A seller should not have to meet exactly the competitor's lower price, for it may be necessary to undercut that price merely to retain a customer. ATT'Y GEN. NAT'L COMM. ANTITRUST REP. 182-83 (1955); Balian Ice Cream Co. v. Arden Farms Co., supra at 802, aff d, 231 F.2d at 366 (dicta). But see Samuel H. Moss, Inc. v. FTC, 148 F.2d 378, 380 (2d Cir. 1945); Standard Oil Co. v. FTC, 340 U.S. 231,247 n.14, 248 (1951).

No court has yet held that a reduction or elimination of a traditional differential between a "premium" brand and a lower-priced product would, per se, negate good faith. Indeed, as consumer preference for the lower-priced product increases, it may be necessary for the premium brand to narrow the differential in order to hold its market. But the Commission has held to the contrary. Anheuser-Busch, Inc., 3 TRADE REG. REP. If 26705 (FTC 1957). Cf. Gerber Prods. Co. v. Beech-Nut Life Savers, Inc., 160 F. Supp. 916 (S.D.N.Y. 1958); Minneapolis-Honeywell Regulator Co., 44 F.T.C. 351, 396-97 (1948). Reduction of a traditional differential by the premium brand seller should be a factor in determining good faith, and it may lead to an inference of intent to drive the competitor from the field. Cf. Porto Rican Am. Tobacco Co. v. American Tobacco Co., 30 F.2d 234 (2d Cir. 1929).

9 The Sun Oil court attempted to draw support from Balian Ice Cream Co. v. Arden Farms Co., supra note 8, but it is clear that that case may be limited by an express holding of no violation of section 2(a). $104 \mathrm{~F}$. Supp. at 805 . Balian involved actions by fifteen ice cream manufacturers alleging, inter alia, that defendant Arden Farms violated Section 2(a) of the amended Clayton Act by an area cut in defendant's wholesale base price of "Flavor Fresh" ice cream from \$1.44 per gallon to S1.06. The district court found that plaintiffs had suffered no loss of gallonage from 1949-1952, except for one party who was no longer in business because of "a forced liquidation and sale to a competitor for reasons not connected with the price reduction." 104 F. Supp. at 805.

Arden gave the area price cut to meet the competition of suppliers offering secret rebates to retailers. Although the district court spoke of the "captive creameries" of large grocery chains, the remark was made in passing. Id. at 805 . Arden did not give the area price cut to meet the competition of the "captive creameries." The analogy between the defensive steps taken by Arden and the action of Sun Oil is tenuous at best, although the Fifth Circuit thought differently:

"Customers supplied by Arden were in competition with retail outlets supplied by the captive creameries. Arden lowered its prices to its customers, retail dealers, to enable them to meet competition at the consumer level. It is clear that the captive creameries did not offer to sell at lower prices to Arden's dealers. Arden, therefore, is in the same position as Sun in the instant case." 294 F.2d at 475 n.26. 
to the "meeting competition" defense of the original Clayton Act10 repudiated by the Robinson-Patman Act.

\section{"SUn OIL": FActs LItigation AND Decision}

Sun Oil is a "major" integrated oil company"1 which in 1955 had thirtyeight retail dealers in the Jacksonville area. One dealer, McLean, operated at the intersection of 19th and Pearl streets a filling station which was owned by Sun Oil and leased to McLean.12 In June, 1955, the Super-Test Oil Company, a "non-major," opened a service station across the street from McLean. Super-Test posted the prevailing price at that time for "non-major" gasoline, 13 but soon embarked upon a series of aggressive price cuts which resulted in substantial increases in gallonage at the expense of McLean.14 Sun Oil took no action on McLean's repeated requests for assistance until December 27, 1955. On that day, following a drop in the Super-Test price from 26.9 cents per gallon to 24.9 cents, Sun Oil offered McLean a "voluntary allowance" of 1.7 cents off the prevailing Sun Oil tank-wagon price. McLean, for the first time since Super-Test entered into competition with him, then reduced his own retail price from 28.9 cents per gallon to 25.9 cents. He thus absorbed 1.3 cents of the allowance by reducing his gross profit margin from 4.8 cents to 3.5 cents. Shortly thereafter Super-Test reduced its retail price to 23.9 cents, thus re-establishing the "usual" two-cent differential between it and

1038 Stat. 730 (1914). Section 2 of the Act read in part: "That nothing herein contained shall prevent ... discrimination in price in the same or different communities made in good faith to meet competition...." (Emphasis added.)

11 For an analysis of the structure of prices and markets in gasoline distribution, see DE Chazeau \& Kahn, Integration and Competition in the Petroleum InUdstry 386-427 (1959); Fellner, Competition AMong the Few 175-83 (1949); 1 Whiney, ANTITrust Policies 95-100, 143-65, 171-87 (1958).

In general the "major" refiners are "conservative competitors" who tend to compete in the offering of services rather than by price battles. It has been said that they are not interested in the profit maximization principle. FELLNER, op. cit. supra at 175-83. See also Cassady \& Jones, Nature of Competition in Gasoline Distribution at the Retail LEVEL 92-97, 108-19, 142-55 (1951); WHITNEY, op. cit. supra at 153-55.

12 There are different types of service stations. The largest percentage of stations are leased by the supplier to the operator; other stations are located on property owned by the dealer or are leased by the dealer from a third party; a small number of stations are operated outright by the supplier or are of the "commission" type, both of which give the supplier full control over retail prices. WHITNEY, op. cit. supra note 11, at 125-26. McLean was in the first category.

13 The "non-majors" are usually aggressive price competitors at the retail level. See generally CASSADY \& JONES, op. cit. supra note 11, at 92-99, 120-41. The price of non-branded gasoline tends to rest at two cents below the price of "major" gasoline. De Chazzau \& KAHN, op. cit. supra note 11, at 466; WHITNEY, op. cit. supra note 11, at 159.

14 Super-Test's large gains are to be explained only in terms of losses by other stations in addition to McLean. See 294 F.2d at 468 n.S. It may be assumed that overall consumer demand for gasoline remained relatively inelastic. WHITNEY, op. cit. supra note 11 , at 179.

The practice of periodic, spot reductions to gain new customers was a normal one for "non-majors." Transcript of Proceedings Before FTC, pp. 510-11. 
McLean. McLean continued to post the 25.9 cent price and experienced a more than five-fold increase in sales of gasoline over his November gallonage until he went out of business on February 18, 1956.15 On February 16 a fullscale price war broke out in the Jacksonville area. Super-Test was forced to lower its price for regular gasoline to 22.9 cents per gallon, and the other majors reduced their tank-wagon prices in the area. Sun Oil then lowered its wholesale price to all its dealers affected.

The Federal Trade Commission issued a complaint against Sun Oil charging violations of Section 2(a) of the amended Clayton Act and Section 5 of the Federal Trade Commission Act. 16 The hearing examiner concluded that Sun Oil had violated 2(a) by the selective price concession to McLean, 17 and that the section 2(b) defense was not available under the Enterprise rule. Even if the defense were available, the examiner reasoned, Sun Oil did not "meet" a lower price in good faith, for it permitted McLean to "beat" a competitor's lower price. ${ }^{18}$ In addition, good faith was negated by the finding of an unlawful retail price-fixing conspiracy between Sun Oil and McLean. ${ }^{19}$ The conspiracy was also held to violate section 5 . The Commission adopted the hearing examiner's findings in full.20

15 The record does not explain precisely why McLean went out of business. His November, 1955, gross profit on gasoline sales was only $\$ 285.42$, while in January, 1956, he grossed $\$ 1,124.03$ from sales of gasoline. But see note 19 infra.

1638 Stat. 719 (1914), as amended, 52 Stat. 111 (1938), 15 U.S.C. § 45 (1958).

17 The Commission's theory of the case was based upon injury to non-favored dealers of Sun Oil in the Jacksonville area, and not on injury to Super-Test. Transcript of Proceedings Before FTC, p. 542. Cf. Pure Oil Co., Trade REg. ReP. (1959 Trade Cases) (FTC December 1959) (initial decision), remanded for additional evidence, TRADE REG. REP. (1959 Trade Cases) I 28370 (FTC 1959).

18 The 1.7 cent price allowance enabled McLean to post a retail price of 25.9 cents, or one cent above the Super-Test price.

${ }^{19}$ Sun Oil admitted that it would not have given McLean the concession had he not lowered his resale price. Brief for Appeliant, p. 40. While no witness testified to an "agreement" between Sun Oil and McLean, it is clear that the dealer was required to take a 1.3 cent cut in his 4.8 cent profit margin in order to obtain the concession. Transcript of Proceedings Before FTC, pp. 95-97. Sun Oil calculated the amount of the discount by its "rule ofthumb" that a dealer needed, at a minimum, a 3.5 cent profit margin, and it assumed that McLean would post a 25.9 cent retail price. $I d$. at pp. 176-77, 512, 514. McLean was dissatisfied with the arrangement, for he could not profitably operate at a 3.5 cent profit margin, as demonstrated by the fact that he was out of business less than two months after receiving the discount. Id. at 237. See also note 15 supra.

20 The hearing examiner also held that, since the McGuire Act, 66 Stat. 632 (1952), 15 U.S.C. $\$ 45$ (1958), applied only to written agreements for fair trade prices, the agreement between Sun Oil and McLean would not be protected by the Florida Fair Trade Law, FLA. Stat. ANN., Ch. 541 (1941). Furthermore, since Sun Oil operated company service stations in the Jacksonville area, it was a competitor of McLean within the meaning of United States v. McKesson \& Robbins, Inc., 351 U.S. 305 (1956), and could not qualify for the protection of the McGuire Act.

The Commission reasoned that the Florida statute sanctioned minimum, but not stipu- 
The Fifth Circuit set aside the cease and desist order, holding that section 2(b) is available "to a supplier of gasoline when the supplier reduces the wholesale price of its gasoline to one of its filling stations engaged in a price battle at the consumer level with a station owned and operated by a competing supplier." 21 The court reasoned that "it is a fiction "to speak of price competition at the oil company sale to the station level." "22 In the court's view Sun Oil was competing for the consumer's business against Super-Test, Sun's independent dealers being mere "conduit[s] between the supplier and the motoring public." 23 For an oil company marketing gasoline through "independents" and "competing with a supplier-retailer," the Commission's view would "excise from the Act the defense of meeting competition." 24 The court would avoid such an effect "by a broad and simple construction: under Section 2(b) a supplier may be in competition with a supplier-retailer." 25

The Fifth Circuit further found no basis for the hearing examiner's conclusion that the 1.7 cent allowance, enabling McLean to post a 25.9 cent retail price, was given to "beat" rather than "meet" competition. ${ }^{26}$ As to the finding of a price-fixing agreement, the court was unimpressed with the hearing examiner's arithmetic and ignored his citation of authorities in support of the

lated, prices. Thus, Sun Oil did not qualify under the McGuire Act as its agreement with McLean did not set a minimum resale price. This rationale disposed of a case holding that the McGuire Act is not limited to fair trade agreements, United States v. Socony Mobil Oil Co., 150 F. Supp. 202 (D. Mass. 1957), certified to the Supreme Court, 252 F.2d 420 (1st Cir. 1958), appeal dismissed per stipulations, 356 U.S. 925 (1958).

Had Sun Oil's agreement with McLean qualified under the Florida Fair Trade Law for the protection of the McGuire Act, it is not clear whether McKesson \& Robbins would subject the company to liability. See Johnson \& Johnson v. Apollo Sales, TraDE REG. REP. I 69919 (S.D.N.Y. April 7, 1961); Johnson \& Johnson v. Avenue Merchandise Corp., TRADE REg. REP. T 69989 (S.D.N.Y. 1961); Eastman Kodak Co. v. Schwartz, 133 N.Y.S.2d 908 (Sup. Ct. 1954); Eastman Kodak Co., 3 TRADE ReG. ReP. If 25291 (FTC 1955) Cf. Esso Standard Oil Co. v. Secatore's, Inc., 1956 Trade Cases If 68547 (D. Mass. 1956), aff d, 1957 Trade Cases \/68695 (1st Cir. 1957), petition for rehearing denied, 1957 Trade Cases :: 68746 (Ist Cir. 1957), cert. denied, 355 U.S 834 (1957); Johnson \& Johnson v. Janel Sales Corp., TRade Reg. ReP. Il 69938 (S.D.N.Y. Feb. 16, 1961); Sinclair Ref. Co. v. Blight Bros., 1960 Trade Cases $\$ 69765$ (Pa. C.P. 1959). See also Comment, Resale Price Maintenance By An Integrated Firm: The McKesson \& Robbins Case, 24 U. CHI. L. REv. 533 (1957).

21294 F.2d at 466-67.

22 Id. at 472 (quoting Enterprise).

23 Id. at 477.

24 Id. at 476.

${ }^{25} I d$. at 481 . (Emphasis added.)

${ }^{26}$ The Fifth Circuit reasoned that the actual differential was greater than one cent in view of Super-Test's practice of giving savings stamps. Id. at 482. But see Safeway Stores, Inc. v . Oklahoma Retail Grocers Ass'n, 322 P.2d 179 (Okla. 1957), aff'd, 360 U.S. 334 (1959).

It was perhaps anomalous for the Commission to claim that Sun Oil enabled McLean to "beat" competition by narrowing the differential to one cent, since, for purposes of satisfying the section 2(a) test of injury to competition, the Commission had only alleged injury to non-favored customers of Sun Oil. 
"implied conspiracy" doctrine.27 While it is fair to assume that sun would not have [lowered its tank-wagon price to McLean] if McLean had intended maintaining his price of $\mathbf{2 8 . 9}$ cents a gallon," the court believed this to be "a long way from a price-fixing agreement." 28

\section{Problems Presented}

Section 2(b) unambiguously limits the availability of the good faith defense. to a seller who endeavors to meet the lower price of a competing seller. ${ }^{29}$ The defense is a deliberate contraction by Congress of an excuse for discrimination that had rendered the original Clayton Act virtually unenforceable. While the former act permitted a seller to discriminate in price "to meet competition," the amended act limits the defense to a discriminatory price offered "to meet an equally low price of a competitor." This change was made in part to curb the power of large buyers to command preferential price treatment. The old proviso was also modified bocause the nature of the competition that could be met was unlimited.30 Decisions preceding Sun Oil gave recognition to this legislative mandate in applying the section 2(b) defense. 31

The Sun Oil court reasoned that a supplier is deprived of a customer no less when the customer is unable to protect his share of the retail market from the advances of an aggressive price-cutter than when the customer changes to a. supplier offering him a lower price. But the "deprivation" theory would permit a seller to discriminate in favor of a particular customer whenever the customer's market position is threatened. Such a construction of the defense would enervate the act. A selker can be "deprived" of a customer in many ways, but if the legishative intent is to be served, "meeting competition" should

2755 F.T.C. 955, 971 m.11, 12 (1959) (initiol decivion). But cf. Standard Oil Co. v. FTC, 233 F.2d 649,654 (7th Cir. 1950, a 4355 U.S. 396 (1958), where the Seventh Circuit reasoned that the "bargaining and hanes" between Standard Oil and the favored dealers, rather than indicating a pricine system, wes evidence of good faith.

28294 F.2d at 483-84. But see note 19 siswa.

29 Sun Oil admitted that section 2(b) refers to the seller's competition. Brief for Appellant, p. 9. The legishative history is clear: 80 CONG. REC. 8235 (1936); H.R. REP. No. 2287, 74th Cons., 2d Sess. (1936). Sec abo note 6 supra. Any other view of $\$ 2(b)$ renders incomprehensible the "services or facilitice" as refarred to in the proviso.

30 See H.R. REP. No. 2951, 74th Cong., 2d Sess. (1936). In 1936, when Congress considered amendments to the Clayton Act, the original Robinson bill in the Senate and Patman bill in the House contained no "meeting competition" provisio at all. The Senate inserted the old Clayton Act proviso in the Robinson bill by amendment; the House passed the Patman bill with a proviso subetantially identical to that contained in the present section 2(b); in conference the Senate version was rejected and the House proviso accepted. See ako 80 Cong. REC. 3113, 3119 (1936). It is rocognized, however, that Congress did not specifically consider and reject the application of $\$ 2(b)$ to a situation such as Sun Oil.

31 Enterprise Indus., Inc. v. Texas Co., 136 F. Supp. 42 (D. Conn. 1955); FTC v. Staley Mfy. Co., 324 U.S. 746, 753 (1945); FTC v. Cement Institute, 333 U.S. 683, 725 (1948); Standard Motor Prod. v. FTC, 265 F.2d 674, 677 (2d Cir. 1959). But of. Balian Ice Cream Co. v. Arden Farms Co., 104 F. Supp. 796, 801-02 (S.D. Cal. 1952), aff'd, 231 F.2d 356, 366 (Gth Cir. 1955). 
be limited to cases where a customer has been offered a lower price by the seller's competitor. ${ }^{32}$

The Sun Oil court, perhaps aware of the pandora's box opened by adoption of the "deprivation" argument, limited its decision to the situation where there is no effective competition among suppliers for a buyer's business. Then the defense would be measured at the resale level, where effective competition among suppliers takes place. The "conduit" theory would regard a supplier and its retailer as a unit; such a construction permits the court to view the competing retailer as the supplier's competitor, within the meaning of section 2(b).

If the court in Sun Oil intended to limit its construction of 2(b) to situations where a supplier's retail dealer is faced with competition in the form of an "integrated" competitor, it gave no indication of the degree of backwardintegration at which the line is to be drawn. If the Ston Oil result is only to occur when a supplier's customer faces competition from a "supplier-retailer:" surely the court should offer an accurate and meaningful definition of "supplier" and an indication of the limits of the rule proposed. The court in Sun Oil made repeated reference to Super-Test as a "vertically-integrated company" which "could fix any price it pleased," and a "supplier-retailer." 33 But the record indicates that Super-Test is no more than a chain of sixty-five retail stations.34 Super-Test was not a "supplier" in the same sense as was Sun Oil. The definitional difficulties that are encountered by resting the availability of section 2(b) on the organizational structure of competitors militate against adoption of such a criterion. There is nothing in the history of the

32 In Standard Oil Co. v. FTC, 340 U.S. 231 (1951), the Supreme Court did not specifically consider the problem raised in Sun Oil, since the lower price offers of competitors were in fact made to customers of Standard Oil. Indeed, there is language in the opinion which indicates a certain sympathy with the defense of the old Clayton Act:

"None of [the changes], however, cut into the actual core of the defense. That still consists of the provision that wherever a lawful lower price of a competitor threatens to deprive a seller of a customer, the seller, to retain that customer, may in good faith meet that lower price." Id. at 242. (Emphasis added.) However, the Court spoke of the right of a seller, in "self-defense" and "as a matter of business survival," to meet the "price paid by a competitor." Id. at 249. The defense was to be available "to retain a customer by realistically meeting in good faith the price offered to that customer. ..." Id. at 250. (Emphasis added.) Sun Oil did not offer McLean the price concession as a matter of business survival on its part. The "offer-counteroffer" language in Standard Oil suggests that the Enterprise limitation was justified. Id. at 244.

See also Anheuser-Busch, Inc. v. FTC, 289 F.2d 835, 840 (7th Cir. 1961): "The competition which is sought to be protected by $[\$ 2(a)]$ is a contest between sellers for a buyer's business ...."; FTC v. Admiral Corp., 1959-60 Trade Reg. Rep., Transfer Binder, I 28175 (FTC, 1959) (subpoena duces tecum denied where documents sought to be produced "related to competititon generally and ... [were] not identified with specific offers by respondent's competitors to customers to whom respondent gave the lower prices...." Id. at 7 37084).

33294 F.2d at 468, 469, 481.

34 Transcript of Proceedings Before FTC, p. 537. 
section which suggests that the defense is to depend upon the fortuitous circumstance of the degree of integration of the price cutting competitor.

The Sun Oil decision indicates an intention to confine 1 - rationale to gasoline distribution, but it is questionable whether the "conduit" theory is necessarily so limited.35 In the ice cream industry, when a large supplier such as Borden's places costly freezers in a retailer's store, the retailer, as a matter of practice, will not change suppliers. In the shirt industry the seller of premium branded shirts who sells to a company such as Marshall Field may not compete for the same customers with the shirt manufacturer supplying a high volume, low overhead operation such as Robert Hall. In both situations posed there may be the same absence of competition for a retail outlet's business as in Sun Oil. The Sun Oil result would permit the ice cream or shirt manufacturer to discriminate in price between competing purchasers, not where the favored retailer was offered a lower price by another supplier, but where that dealer simply needed a discriminatory price to compete with a lower-priced, high volume competing retailer.

The "conduit" theory thus results in as expansive a construction of the "meeting competition" defense as the "deprivation" theory. Both theories permit the seller to discriminate in favor of a buyer in order to meet general competitive conditions. Such a view of the defense has been repudiated by a line of cases from FTC v. Staley Mfg. Co.36 to Standard Motor Prods. v. FTC.37 The "conduit" theory will vitiate the effectiveness of the Robinson-Patman Act by expanding the defense so as to make it indistinguishable from the old Clayton Act. 38

It has been argued that since the prohibitions of section $2(a)$ include discriminations having adverse effects upon buyers, the section 2(b) defense should be correlative with the offense: "A multi-tiered condemnation requires a multi-tiered defense." "39 Logic does not compel a court to make the defense coextensive with the offense. Standard Oil implicitly rejected such a view. 0 Were Sun Oil to have interposed jobbers between it and retail stations,

35 Even if the Sun Oil result were to be limited to the gasoline industry, which the Fifth Circuit did not make clear, it is not to be perceived what public policy is served by carving out such an exception from the antitrust laws. See United States v. Socony-Vacuum Oil Co., 310 U.S. 150, 222 (1940). But cf. United States v. National Football League, 116 F. Supp. 319 (E.D. Pa. 1953).

36324 U.S. 746 (1945).

37265 F.2d 674 (2d Cir. 1959), cert. denied, 361 U.S. 826 (1959).

38 Arguably, the Standard Oil case itself enlarged the section $2(\mathrm{~b})$ defense beyond the limits intended by Congress. See discussion supra in note 4.

${ }^{39}$ Sun Oil Co. v. FTC, 294 F.2d 465, 477 n.34 (5th Cir. 1961) (quoting Steed, Antitrust Problems Under Price War Conditions, SOUthwestern INSTItLTe ON ANTI TRLst Laws (1958.))

4 Standard Oil, in refusing to permit the Commission to weigh the adverse effects upon competition at other levels against the beneficial effects of the seller's meeting competition at its own level, suggests that the Supreme Court will not permit the necessities of competition at such other levels to determine the extent to which a seller may assert the defense. 
and were the Commission to have disregarded the jobbers and charged a violation of section 2(a) for discrimination among the indirect purchasers, ${ }^{41}$ it would then seem only proper to permit the refiner also to ignore the jobbers and show that it was meeting the competition of lower price offers to the retailers. But where a seller such as Sun Oil is not impressed with the obligations and liabilities of operating at other than its own level, that seller should not be permitted to meet competition at such other levels.

The court in Sun Oil argued that a selective price concession by a "major" gasoline supplier to one of its dealers in competition with a price-cutting "nonmajor" "benefit [s] consumers and the competitive process in at least two ways: by promoting competition at the retail level and by providing an opportunity for a major to break away from a uniform pricing system characteristic of an oligopolistic industry such as the oil industry." 42 To the contrary, Sun Oil may well protect "oligopolistic industry" in its attempt to free competition.43

Advocates of "workable competition" 44 have recognized the need for aggressive "non-majors" in the oil industry as a healthy antidote to the nonprice competition of "major" suppliers. ${ }^{45}$ But Sun Oil permits the large yet only partially-integrated supplier to extend its power forward into retailing, where it has deliberately chosen to use "independent" dealers. To permit a supplier to complete at its dealer's level, for purposes of the "meeting competition" defense, is to allow the oligopolist to protect the "system" at the expense of non-favored retailers and to check in its incipiency the growth of independents who threaten the status quo. This conflicts with the purpose of the Robinson-Patman Act, which was to prevent, in their incipiency, conditions which would tend to destroy competition among buyers. ${ }^{46}$ In the guise

41 See Dentists' Supply Co., 37 F.T.C. 345 (1943); Luxor, Ltd. 31 F.T.C. 658 (1940); Kay Windsor Frocks, Inc., 51 F.T.C. 89 (1954); Kraft-Phenix Cheeze Corp., 25 F.T.C. 537 (1937); General Motors Corp., 50 F.T.C. 54 (1953); Electric Auto-Lite Co., 50 F.T.C. 73 (1953); Liggett \& Meyers Tobacco Co., Trade REG. REP. (1959 Trade Cas.) I 28256 (FTC 1959); Fruitvale Canning Co., Trade Reg. REP. (1956 Trade Cas.) I 26069 (FTC 1956); Krug v. International Tel. \& Tel. Corp., 142 F. Supp. 230 (S.D.N.J. 1956). $C f$. Klein v. Lionel Corp., 138 F. Supp. 560 (D. Del. 1956), aff'd, 237 F.2d 13 (3rd Cir. 1956); Sano Petroleum Corp. v. American Oil Co., 187 F. Supp. 345 (E.D.N.Y. 1960); Secatore's, Inc. v. Esso Standard Oil Co., 171 F. Supp. 665 (D. Mass. 1959).

42294 F.2d at 474-75.

43 Cf. Standard Oil Co. of California v. United States, 337 U.S. 293 (1949); Schwartz, Potential Impairment of Competition, 98 U. PA. L. REV. 10, 15, 36-37 (1949). See MACHIU?, THE ECONOMICS OF SELLERS' COMPETITION, 347-540 (1952).

4 E.g., FeLLNER, op. cit. supra note 11, at 292-311.

45 Rostow \& Sacks, Entry Into The Oil Refining Business: Vertical Integration Re-Examined, 61 YALE L.J. 856, 860-61 (1952). Sun Oil penalizes vertical integration by non-majors, but for such newcomers, integration is "a defensive response to the facts of life in an oligopoly." Id. at 914.

46 It has been argued that the incipiency doctrine inherent in the Robinson-Patman Act tends to strike at deleterious effects before they even appear. The act "curbs price differences when, in a larger sense, no effect on competition is visible." Levi, Antitrust Policy in Distribution, ABA ANTITRUST SECTION 97 (1955). 
of "meeting competition" the "major" supplier may effectively beat the only competition he need fear-price competition.

There is every indication that the "majors" will not use selective price concessions to "break away from a uniform pricing system ...."47 Price discrimination ${ }^{48}$ as approved in Sum Oil may entrench imperfect competition and provide the means for reinforcing a rigidly adhered-to pricing system by disciplining price cutters and discouraging deviation from established differentials. $4 \cdot \dot{A}$ voluntary price concession may act as a "lightning rod" to preyent breaks in the structure from spreading. Meeting competition in this manner neither initiates lower prices nor extends price offers to any consumer who did not have the competing lower price offer already available.

The causes of retail gasoline price wars stem from deep-seated imbalances in the system, 50 and neither the Fifth Circuit nor the Commission construction of section 2(b) will curb the disruptive aspects of price wars. Indeed, any attempt to do so may end in stifling price competition itself. Selective price cuts may be so provocative as to accentuate a price war, or they may meet at the outset a competitor's lower price and dissuade him from aggressive price cut-

47294 F.2d at 475. See CAssudy \& JONEs, op. cit. supra note 11, at 92-97.

45 Price discrimination is a characteristic of imperfect market conditions, a reflection of incomplete integration. Dnuay \& KaAn, FAlR COMPETITION 202 (1954); Rowe, Price Discrimination, Competition \& Confusion: Another Look at Robinson-Patman, 60 YaIE L.J. 929. 931-32 (1951); DE Cenazeau \& Kafn,"op. cit. supra note 11, at 470. Price discrimination awands victory, not to the more efficient operation, but to the superior purse. Discrimination is an inexpensive way of protecting one's market position without resorting to price cuts. For a description of price discrimination in the oil industry, see De Chazrau \& Kafin, op. cit. supra at 461-71.

A theory of monopolistic competition might defend price discrimination on several grounds: by secret rebates, an oligopolist can attempt promotional pricing selectively, while the alternative might be no price flexibility and higher average prices; where excess capacity exists, discrimination could result in fuller utilization of plant. See DIRLAM \& KAHN, op. cü. sugra at 204-09.

$49 \mathrm{DE}$ Chazeau \& KaHn, op. cit. supta note 11, at 467.

so Gasoline price wars have been carefully studied. See, Hearings, Subcommittee on Retailing, Distribution and Fair Trade, Select Committee on Small Business, U.S. Senate, 84th Cong., Ist and 2d Sess. (1956), and the Report of the hearings, "Gasoline Price War in New Jersey," S. REP. No. 2810, 84th Cong., 2d Sess. (1956); Note, 101 U. PA. L. Rev. 644 (1953).

Often price wars are directly traceabie to the existence of an excess supply of gasolime as against an inelastic demand, and to the major refiners" practice of "dual distribution" to dispose of their excess stocks. As a result of the disinclination of major refiners to divorce themsetves from active participation at the retail level, they try to dispose of the excess stocks to independents and, by price discrimination, protect their own dealers from the effects thereof. See, Business Week, Oct 6, 1956, pp. 146, 149-50; S. REP. No. 2810, supra at 18-19; DE CHAZEAU \& KABN, op. cit. supta note I1, at 454-61; WhITNEY, op. cit. supra note 11, at 160-62. In Sun Oil there was no proof that the company had followed the practice of "dual distribution."

A price war may disrupt established lines of distribution, put very real pressures on innocent retailers, and result in spasmodic, indiscriminate price competition. On the other hand a price war facilitates entry of independents and loosens the hold of major refiners on retail prices by. preventing the refiners from setting tank-wagon prices at too high a level. 
ting. 51 Because it poses a very real threat to the continued existence of retail price competition, and because it violates the letter and spirit of the RobinsonPatman Act, such price discrimination should not be permitted under section 2(b). 52

To forbid voluntary price concessions will not be to force higher average prices on the consuming motorist. The fear of aggressive price competition by "non-majors" will prevent "major" refiners from setting their tank-wagon prices too high. With the safety valve of price discrimination closed, downward revision in tank-wagon prices may result. 53

One alternative to selective price concessions is to withhold help from the station in distress. While this runs counter to some commonly accepted notions of "meeting competition," 54 it is not necessarily an "intolerable burden"5s on the affected dealer. A course of non-action by the supplier may give the pricecutter a competitive advantage, but it is not clear that the Commission's construction will have the effect of "fostering vertical integration at the expense of the small, independent retailer."'s6

SI It appears impossible to state with certainty whether a particular discriminatory price concession will invigorate or sap the vitality of price competition in the area affected, or whether it will intensify the price war or curtail it. For discussion of the pros and cons of selective price concessions, see S.REP. No. 2810, supra note 50; DE CHAZEAU \& KAFN, op. cit. supra note 11, at 461-77, 476-83; WHITNEY, op. cit. supra note 11, at 160-62; CAssadY \& JONES, op. cit. supra note 11, at 99 . For studies of the Canadian approach to the problem, see Restrictive Trade Practices Commission, Department of Justice, Ottawa, Reports nos. 12,13 and 14 (1961).

52 It is recognized that the practice of granting volumtary price concessions can be proscribed only at the cost of declaring improper widely held views of "meeting competition." De ChazeAu \& KAHN, op. cit. supra note 11, at 479 . Such concessions might be condoned if the Standard Oil rule, that the defense is absolute, is modified. In that case there was present the classical situation of two suppliers vying for the business of a single buyer, while in Sun Oil a supplier wanted to discriminate in price in order to meet competition at the resale level. To make the defense absolute in the latter, more sophisticated situation, is to give the supplier carte blanche to destroy competition at the resale level. Markham, The Report of the Attorney General's Committee on the Antitrust Laws, 70 Q.J. EcoN. 193, 210 (1956). See also note 4 supra.

In Canada voluntary price concessions are prohibited only when "granted as part of a practice of discriminating ..." Criminal CODE OF CANADA \$412(2) (1959). [Section 33(a), Combines Investigation Act]. (Emphasis added.)

53 See DiRLaM \& KAHN, op. cit. supra note 48, at 250-51.

54 "Behavior which is natural to firms when they are acting as competitively as they can, now becomes, under some conditions, a violation of law." Levi, The Robinson-Patman Act -Is It In The Public Interest? 1 ABA Section of ANTITRust LAw, 60, 64 (1952).

ss Sun Oil Co. v. FTC, 294 F.2d 465, 479 (5th Cir. 1961). See Note, 101 U. PA. L. Rev. 644, 645-46 (1953) (Esso dealer who converted his station into a multipump operation successful in competing with a price-cutting "non-major" at only 1.2 cent profit margin).

56 The past history of the petroleum industry belies such an argument. The "majors" have not wanted to suffer the burdens of inflexibility at the retail level and the higher costs that integration-forward by ownership involves: "it is unlikely that ownership integration can or does serve as an escape hatch from all the problems this act poses for contract vertical integration." Kessler \& Stern, Competition, Contract and Vertical Integration, 69 YAlE L.J. 1, 127 (1959). See also WhITNEY, op. cit. supra note 11, at 125-26. 
Another alternative is an area price reduction. While this does not necessarily "run afoul of Anheuser-Busch, " "s7 there is the possibility that a supplier granting such a price cut will be said to have violated the good faith requirements of section 2(b). Such a result may be avoided, as in Balian Ice Cream Co. $v$. Arden Farms Co., $\$ \delta$ by giving the supplier a reasonable measure of discretion in determining the boundaries of the area affected. $s 9$ In Balian the supplier was permitted to grant an area price cut to meet the competition of other suppliers offering secret rebates to customers, selective price cuts being impracticable.

A final difficulty with the Sun Oil view is that by permitting the supplier to exercise a powerful voice in the price decision-making of its retailer, the Fifth Circuit would bring the Robinson-Patman Act into needless conflict with antitrust law prohibiting resale price maintenance. 60 It was only by a con-

57 Sim Oil Co. v. FTC, 294 F.2d 465,480 (5th Cir. 1961). Balian Ice Cream Co. v Arden Farms Co., 104 F. Supp. 796 (S.D. Cal. 1952), affd, 231 F.2d 356 (9th Cir. 1955), cert. deried, 350 U.S. 991 (1956), supports the view that an area price cut may be offered with impunity so long as there is no injury to competition. Since an area price reduction, by definition, would be offered to all competing purchasers, the only actionable discrimination would be primary line injury. Atlas Bldg. Prods. Co. v. Diamond Block \& Gravel Co., 269 F.2d 950 (10th Cir. 1959). This view finds support in the Supreme Court opinion in FTC 1. Anheuser-Busch, Inc. 363 U.S. 536, 552 n.21 (1960). The requisite primary line injury for a section 2(a) violation would not have been present had Sun Oil offered an area price cut to its Jacksonville deakers. Balian Ice Cream Co. v. Arden Farms Co., supra: AnbeuserBuach, Inc. v. FTC, 289 F.2d 835 (7th Cir. 1961); General Gas Corp. v. National Utiv. Inc., 271 F.2d 820 (5th Cir. 1959). Sec Adelman, Geographical Price Differentials, 48 ILL. B. J. $514,524-27(1960)$.

58 104 F.Supp. 796 (S.D. Cal 1952), aff d., 231 F.2d 356 (9th Cir. 1955), cert. denied, 350 U.S. 991 (1956).

5) For other proposals to ameliorate the adverse effects of retail price wars, see Note, 101 U. PA. L. REV. 644, 658-60 (1953); S. REP. No. 2810, supra note 50, at 19-26; WfITNEY, op. eir. npra note 11, at 161-62

The trend to "commission" sales indicates the possibility of a satisfactory alternative for the majors. See Simpson v. Union Oil Co. of California, TraDE REG. REP. T 69936 (N.D. Cal. 1960). Cf. United States v. Richfield Oil Corp.s 99 F. Supp. 280 (S.D. Cal. 1951), aff $d$ per curiam, 343 U.S. 922 (1952). The supplier could operate at the retail kevel by agency agrements without running the risk of prosecution for resale price fixing. G. D. Searle v. Institutional Drug Distrib., Inc., 151 F. Supp. 715 (S.D. Cal. 1957); United States v. General Eloc. Co., 272 U.S. 476 (1926). But see Dr. Miles Co. v. Park \& Sons Co., 220 U.S. 373 (1911). Cf. Vietor Talking Mach. Co.v. Kemeay, 271 Fed. 810 (3rd Cir. 1921); Ford Motor Co. v. Union Motor Sales Co., 244 Fed. 156 (6th Cir. 1917).

so When designed to operate vis-z-vis the general consuming market and to fix prices in that mariket, horizontal or vertical agreements to fix minimum, maximum or stipulated prices are illegal per se. Kiefer-Stewart Co. v. Joseph E. Seagram \& Sons, Inc., 340 U.S. 211 (1951); United States v. Univis Lens Co., 316 U.S. 241 (1942); United States v. SoconyVacturm Oil Co., 310 U.S. 150, 223 (1940).

It has been argued that 2 seller might "compel price matching" in a situation such as Sun Oil; that an agreement with a favored buyer "need not be deemed a price fixing agreement which is illegal per se," for "neither the purpose nor the effect of the agreement is to climinate price competition in the retail market, but rather to enable the seller to compete with rival sellers without violating the Robinson-Patman Act" Note, The Good Faith Defense of the Robinson-Patman Act: A New Restriction Appraised, 66 YALE LJ. 935, 944-45 (1957). See Board of Trade v. United States, 246 U.S. 231 (1918); Appalachian Coals, Inc. v. United States, 288 U.S. 344 (1933); United States v. Columbia Pictures Corp., 1960 
scious relaxation of Sherman Act directives that the court in Sun Oil could deny the presence of an implied agreement to fix prices at the retail level.61

Trade Cases I 69766 (S.D.N.Y. 1960); Harriet Hubbard Ayer, Inc. v. FTC, 15 F.2d 274 (2d Cir. 1926). However, the continued vitality of the Board of Trade and Appalachian Coals cases is to be questioned, the former having been expressly limited to its facts in United States v. Trenton Potteries Co., 273 U.S. 392, 401 (1927), and the latter effectively distinguished in Socony-Vacuum, supra at 216. Columbia Pictures and Ayer might be distinguished in that neither involved an agreement to fix prices. The argument in favor of "incidental" price-fixing is in disrepute.

Sun Oil's motives are irrelevant if in fact it agreed with McLean as to the resale price to be charged. Radovich v. National Football League, 352 U.S. 445, 453 in.10 (1957); Fashion Originator's Guild of America, Inc. v. FTC, 312 U.S. 457, 468 (1941). Nor is the setting of a maximum resale price any the less unlawful than a minimum price. Kiefer-Stewart Co. $v$. Joseph E. Seagrams \& Sons, supra at 213; United States v. White Motor Co., Trade Reg. REP. I 70025, at I 78081 (N.D. Ohio April 21, 1961).

While resale price maintenance in intrastate commerce has been declared lawful in some states, Marsich v. Eastman Kodak Co., 244 App. Div. 295, 299, 279 N.Y. Supp. 140, 146 (2d Dept. 1935), aff'd, 269 N.Y. 621, 200 N.E. 27 (1936), it is clearly unlawful if declareci to be an unfair method of competition in interstate commerce under Section 5 of the Federal Trade Commission Act. FTC v. Beech-Nut Packing Co., 257 U.S. 441 (1922).

Whether a sporadic, conditional price discrimination would violate that act is not settled. See United States v. Bausch \& Lomb Optical Co., 321 U.S. 707 (1944) ("systematic price suggestions" unlawful whether achieved by agreement or by acquiescence). In Beech-Nut the Court had declared that there is "suppression of the freedom of competition by methods in which the company secures the cooperation of its distributors and customers, which are quite as effectual as agreements express or implied intended to accomplish the same purpose." 257 U.S. at 455 . Mr. Justice Brennan, speaking for the Court in United States v. Parke-Davis Co., 362 U.S. 29 (1960), construed Beach-Nut "as holding that the nonexistence of contracts covering the practices was irrelevant." Id. at 41. The Parke-Davis case involved a plan for the maintenance of minimum resale prices by a manufacturer of pharmaceutical products. The plan included informing wholesalers that the manufacturer would refuse to deal with them if they sold the manufactuer's products to offending retailers, and inducing retailers not to advertise the manufactuer's products below its minimum retail prices. Parke-Davis was not a case of "systematic" resale price maintenance. See Finding No. 10, 164 F. Supp. 827, 831 (D.D.C. 1958). It was held that this plan violated the Sherman Act even in the absence of an agreement, express or implied, concerning resale price maintenance, because an unlawful combination exists "if the producer secures adherence to his suggested prices by means which go beyond his mere declination to sell to a customer who will not observe his announced policy." 362 U.S. at 43.

An observer has said of the above language: "This seems to be a rather mechanical application of language if applicable to situations where restraints were less widespread and first vendees were not incorporated into an enforcement system over subsequent purchasers." Levi, The Parke, Davis-Colgate Doctrine: The Ban on Resale Price Maintenance, 1960 SuP. Cr. Rev. 258, 311-12. Moreover, "It is one thing ... to say that Beech-Nut involved methods quite as effectual as agreements, express or implied, and quite another thing to say that any contract or combination which goes beyond a refusal to sell to price cutters is an actionable restraint of trade." Id at 300 . Thus it is questionable whether the conditionable price discrimination in Sun Oil would come under the ban of Parke-Davis, since there is no restriction on subsequent purchasers nor use of purchasers to effect a boycott of non-complying parties. The policy of Sun Oil was, as Mr. Justice Harlan said of Parke, Davis, a "defensive, limited, unorganized, and unsuccessful effort . . . " 362 U.S. at 56 (dissenting).

61 See note 19 supra. See also 55 F.T.C. $955,967-72$ (1959). It is questionable whether the Fifth Circuit gave proper consideration to the hearing examiner's assessment of the credibility of witnesses. See Vacu-Matic Carburetor Co. v. FTC, 157 F.2d 711 (7th Cir. 1946); Quality Bakers of America v. FTC, 114 F.2d 393 (1st Cir. 1940). 


\section{Concluston}

Section 2(b) does not present an irreconcilable conflict between the Robinson-Patman Act and the antitrust laws.62 The "conduit" theory adopted by the Sun Oil court is a circumvention of the manifest legislative intent to limit the availability of the defense to a seller whose competitor has offered a lower price to a customer. The Robinson-Patman Act was not designed for the exifencies of particular industries and was not structured to except from its prohibitions a particular system of distribution. Because the Supreme Court hes inticated an unwillingness to superimpose judicial economic predilections upon an expressed mandate of the Act,63 a Sin Oil result disregards this poticy.

62 C. Automatic Canteen Co. of America v. FTC, 346 U.S. 61 (1953).

c3 FTC v. Henry Broch \& Co., 363 U.S. 166 (1960); FTC v. Simplicity Pattern Co, 300 U.S. 55 (1959). 